\title{
Core or Immersion? Canadian French-Second-Language Teacher Candidates' Perceptions and Experiences of the Best and Worst Program Options for Students with Learning Difficulties and for English Language Learners
}

\author{
Katy Arnett \\ St. Mary's College of Maryland \\ Callie Mady \\ Nipissing University
}

\begin{abstract}
Responding to the needs of and/or including students with different need profiles has been an area of focus within Canadian French Second Language (FSL) education for many years. This study draws on quantitative data from two questionnaires (administered before and after Canadian teacher candidates in FSL education completed their practica) and on qualitative interview data from a volunteer sample of questionnaire participants. The purpose of the study was to explore how these participants viewed the best and worst FSL program options, among four choices, for students who had learning difficulties or who were English language learners, and to see the extent to which these views could be linked to their practicum experience. Though some participants did mention less common programs, most participants restricted their responses to the traditional FSL program dichotomy of core French and French immersion. We noted differences in the participants' views according to the program of their student teaching practicum and according to the learning need under consideration. Implications for FSL teacher education and FSL education are discussed. In particular, we recommend providing research information to teacher candidates at the Bachelor of Education level in order to encourage teacher candidates to consider evidence as they move toward greater inclusion in FSL; given that these future teachers will need to support varying student needs in their career, this information should be included in their preparation.
\end{abstract}


Across Canada, core French and French immersion programs have historically been the two options for French Second Language (FSL) study. ${ }^{1}$ Though Ontario is unique in offering an Extended French program option, and the Intensive French program developed in Newfoundland continues to expand across the country, most conceptions of FSL programming choice consider the dichotomy of core French and French immersion. Besides comparing the program structures and outcomes, the research literature has sometimes positioned these two FSL contexts against each other when exploring how teaching practices and program expectations align with the specialized needs of certain learner populations, including, among others, students with learning difficulties (LD) and other special needs (e.g., Arnett, 2003; Genesee, 2007; Mannavaryan, 2002), and newcomer students to Canada who are also learning English (e.g., Carr, 2007; Mady, 2007a). These two learner populations have been brought together in this study because the "suitability" of both groups for FSL study has historically been questioned, whereas current educational policies are heavily oriented toward an inclusion paradigm that advocates for respect and support of a diverse range of learning needs (e.g., Canadian Parents for French, 2012; Porter \& AuCoin, 2012). While these two groups were examined together in this study, in practice, teacher candidates' perceptions and pedagogical choices will, at times, differ between the groups.

The purpose of the current study is to explore how teacher candidates in FSL view these two programs in relation to the question of the best and worst programming option for students with LD and for English Language Learners (ELL), and to examine the extent to which their views could be linked to their experiences in the programs during their Bachelor of Education (B.Ed.) year. The data for this particular inquiry come from a larger pan-Canadian longitudinal study of FSL teacher candidates during their B.Ed. year and into their first four years of teaching. This article draws first on selected data from two questionnaires, one administered prior to and one following their practicum experiences in the B.Ed. year, and then from semi-structured interviews with a smaller subset of participants who expressed a willingness to become informants for the project. Specifically, this study seeks to answer the following questions:

1. How do FSL teacher candidates' experiences in these programs align with perceptions of best programming options for students with LD and for ELLs?

2. In the case of the candidates who were interviewed, does the program in which they taught align with their perceptions of the best and worst programming options for these student populations?

\footnotetext{
${ }^{1}$ Core French is a program in which French is taught as a subject for one period each day or several periods each week, approximately 40 minutes per day in elementary school or 75 minutes per day for one semester in a semesterized secondary school. French immersion is a program in which students study the language and other subjects delivered in French for at least $50 \%$ of their instructional time. Extended French is a program in which students study the language and other subjects delivered in French for at least $25 \%$ of their instructional time. Intensive French is a program in which French is taught intensively for most of the day during five months in Grade 5 or 6 , followed by a schedule resembling core French for the rest of the initial year and subsequent years.
} 
Though this paper has a narrow content focus with a small participant population, it nonetheless offers an important glimpse into how those entering the teaching profession could influence the way students with LDs and ELLs are supported in the classroom.

\section{Literature Review}

Students with LD. For nearly forty years, there have been questions about whether FSL study for students with LD, ${ }^{2}$ particularly in the immersion context, is a "suitable" or "appropriate" programming choice (see Genesee, 2007, for a review of much of the research). Despite evidence that students with learning-related challenges are at no greater risk for failure in French immersion than they are in the English programs and that French immersion remains the FSL program with the best learning outcomes (Genesee, 2006, 2007; Lazaruk, 2007), perpetual dialogues about transferring struggling students to the English stream tend to imply that core French study is a better match for the needs of the students with LD. Arnett $(2003,2010)$ has shown how teachers are able to deploy recommended strategies for supporting students with LD and other special needs in the core French context, but there are also data confirming that French immersion teachers can support students with LD and other special needs in their classrooms (e.g., Le Bouthillier, 2013; Rousseau, 1999). On a different, but related track, Arnett (2013) points out that the policies and practices related to limiting access by or counseling out or removing students with LD from French immersion programs seemingly raised questions about the appropriateness of FSL study for any student with LD, giving rise to the practice of exempting students from FSL study altogether.

English language learners. The shift in Canadian immigration patterns from countries of the British Commonwealth to the countries of east and south Asia during the 1980s led to changes in learner populations in Canadian schools and, by consequence, in their learning needs (Statistics Canada, 2011). More students who did not speak English or French as their home language began to enrol in school, and educators began to notice these students in FSL programs (e.g., Swain, Lapkin, Rowen, \& Hart, 1990; Taylor, 1992). In addition to educators, academics (Swain \& Lapkin, 2005) highlighted that inclusion of ELLs in the French immersion program in particular had prompted a reconsideration of the foundations of French immersion. As Mady (2007a) showed in her initial literature review of this issue, there were uneven policies and practices informing the educational experience of these students in FSL programming. In some school districts, these ELLs were either overtly restricted from studying FSL - a practice that was and still is referred to as an exemption - or allowed to enrol in the programs without any noted concerns about their participation (Taaffe, Maguire, \& Pringle, 1996). More recent reviews (Mady \& Black, 2012) reveal that that this unevenness persists; and in situations in which the exemptions are still in place, it appears that the primary rationale is often informed by a belief that this student population cannot manage learning two languages simultaneously, or that their language learning efforts are best spent focusing on English, as that is the dominant language of schooling. Similar to students with LDs,

\footnotetext{
${ }^{2}$ For the purpose of this paper, we are using the broader term learning difficulties rather than learning disabilities to acknowledge the reality that "unofficial" learning challenges have sometimes been used as a rationale to exclude or limit students' access to FSL study.
} 
decisions to exempt ELLs from FSL learning opportunities are made in spite of research showing their potential to succeed in both core French (Mady, 2007b) and French immersion (Mady, 2015) programs.

Teacher perceptions about core French and French immersion. Within the field of FSL education, much of what is understood to be true about teacher perceptions of core French and French immersion programs and about the students enrolled in these courses has been largely anecdotal. Though there have been smaller studies-usually at the scale of a case study or exploratory case study - that have queried the beliefs and perceptions of the teachers who have been under consideration (e.g., Knouzi \& Mady, 2014; Thomas \& Mady, 2014), only one formal study has considered the views and, to some degree, the experiences of FSL teachers across Canada.

In 2006, with support from the Canadian Association of Second Language Teachers, the Canadian Association of Immersion Teachers, and the Canadian Teachers' Federation, Lapkin, MacFarlane, and Vandergrift completed a two-part pan-Canadian questionnaire study of FSL teachers' perceptions about their work in the program. In addition to gathering general data about the participants, including their self-assessed proficiency in French, the program(s) in which they taught, their pre-professional education, and intended goals for remaining in the profession, the questionnaires focused on four particular areas: (a) their perceptions of the quantity and quality of the resources available to them to teach French, (b) their perceptions of the other resources available to them to support their work in the classroom (e.g., planning time, classroom space, personnel who could help with questions about content and/or student needs), (c) their perceptions of the support given to them by various stakeholders (e.g., other school personnel school and parents), and (d) their perceptions of how they could handle the various demands of their teaching duties (Lapkin et al., 2006). None of the questions in this study directly asked the teachers' perceptions of certain student populations and/or of their needs in the classroom, yet within the findings of the study, there are various data points of relevance to the current work.

Lapkin et al. (2006) found that the majority of the respondents to this study were core French teachers $(55.8 \% ; n=1,274),{ }^{3}$ but it is worth noting that a slightly higher percentage of participants $(58.5 \% ; n=1,378)$ reported receiving their own French language education through core French programs. Further, nearly $10 \%$ of the respondents in this study were self-identified as allophone $(9.3 \% ; n=118)$.

The results of Lapkin et al. (2006) also revealed that core French teachers were generally more satisfied with the quality of resources available to them to teach French, as French immersion teachers often reported difficulty in finding resources that were linguistically and developmentally appropriate for the students' current level of content study in French. Such results could have an influence on the extent to which teachers perceive that French immersion is able to support students with less typical learning

\footnotetext{
${ }^{3}$ Within the research report of this study, for each question the authors report both a percentage and count value $(n)$. A total of 1,305 participants completed the questionnaire of perceptions, but as many as 100 participants skipped some questions. Thus, results are reported here with the percentage and $n$ value for each individual question.
} 
needs, which has been reported in other research (e.g., Genesee, 1976, 1990, 2006, 2007). However, core French teachers reported a disadvantage in classroom space, in that nearly $40 \%$ of the core French teachers did not have a classroom space to call their own. As many of the core French teachers would travel around the school to teach students in their regular classrooms, they were less able to create a learning environment where French was physically featured beyond their instruction and/or to establish classroom management practices that aligned with how they wanted to support instruction. In brief, both contexts were perceived as having some disadvantages that could influence whether and/or how students may be viewed as "suitable" participants in the learning community.

At the conclusion of the Lapkin et al. (2006) survey, participants were asked a series of open-ended questions. Question 31 of the survey asked participants to identify their top three challenges in teaching French (2006, p. 30). Eighty-nine responses were collected for this question, and, as the report revealed, the "diversity" of the student population within FSL was of greatest concern to the teachers:

The challenge most often cited $(13.8 \%)$ by teachers concerned the diversity of the students in their FSL classroom; both core French and French immersion teachers cite this challenge equally often. It appears that the range of students in one class (different FSL abilities, ESL [English as a second language] students, special education students), without adequate support, represents the greatest overall challenge for the FSL teacher. (Lapkin et al., 2006, p. 31)

Such pan-Canadian findings are supported by one provincial study. In Ontario, Mollica, Phillips, and Smith (2005) used a questionnaire to gather data from 1,500 elementary core French teachers. When offered the opportunity to provide additional information after having completed the quantitative items of the questionnaire, the teachers revealed their discomfort in their abilities to meet the needs of diverse students.

While the current study explored the perceptions of individuals who had not yet officially entered the FSL classroom as teacher, an awareness of the perceptions held by active teachers, as documented in the literature, could provide a useful frame of reference for our results.

\section{Methodology}

The present study uses data from three tools: (a) a pre questionnaire, administered prior to teacher candidates' first practicum in their teacher education program; (b) a post questionnaire, administered following the majority, if not all, of the practicum in their teacher education program; and (c) responses from nine participants who agreed to be later interviewed. Those semi-structured interviews were recorded and transcribed.

\section{Participants}

In all, 78 teacher candidates responded to the pre-questionnaire. Subsequently 51 teacher candidates responded to the post questionnaire, 48 of whom had also completed the pre questionnaire. The findings below are from those participants who responded to both pre and post questionnaires $(N=48)$. The number of respondents varies per question because, per ethics guidelines, participants could choose not to respond to a question. For 
additional details about the demographics of this participant pool, see Mady, Arnett, \& Muilenburg, 2016. As it pertains to the participants, Table 1 shows the FSL program in which they had their practica.

Table 1

\section{Percentage of Participants According to FSL Program Experience}

\begin{tabular}{lc}
\hline In which program(s) did you have your practicum? $(\boldsymbol{n = 4 6 )}$ & $\mathbf{\%}$ \\
\hline Core French & 54.9 \\
French Immersion & 31.4 \\
Extended French & - \\
Intensive French & 3.9 \\
Other & - \\
\hline
\end{tabular}

\section{Questionnaire}

The questionnaire (see Appendix) was created for the purpose of this study. It provided ten demographic questions followed by two 5-point Likert scale-of-agreement sections that included a neutral option, neither agree or disagree. The two Likert-scale sections were: (a) one with 15 items pertaining to the inclusion of ELLs (e.g., "I believe ELLs should be included in core FSL classes") and (b) one with 18 items pertaining to the inclusion of students with LDs (e.g., "I believe students with LDs should be included in French immersion, where available"). These two sections formed the post questionnaire. For the purposes of this paper, the focus is on the four items that pertain to the inclusion of all students, ELLs, and students with LDs, according to program.

\section{Analysis}

Frequencies were generated for all closed-ended items on the questionnaire combining the two positive points on the scale (i.e., strongly agree and agree) and the two negative options (i.e., strongly disagree and disagree) responses to reflect teacher candidates' perceptions (Boone \& Boone, 2012). Relationships were explored between responses on the Likert-scale items for inclusion of ELLs and students with LDs and the program of practica. Specifically, a chi-square analysis was conducted using the statistical software package $\mathrm{R}$ to compare the proportion of respondents who agreed with items pertaining to the inclusion of all students, ELLs, and students with LDs. An effect size, Cohen's $h$, was also computed to examine the strength of the difference between teacher candidates' experiences across programs. Cohen's $h$ is the recommended effect size when comparing two proportions (Cohen, 1988). Such a computation is particularly pertinent given the practical experience of the participants and the potential practical implications in the field of education, where effect size can be used to evaluate practical significance (Maher, Markey, \& Ebert-May, 2013). To interpret the strength of the difference between the levels, the following criteria were used: $h=.20$, small effect; $h=$ .50 , medium effect; and $h=.80$, large effect (Cohen, 1988). 


\section{Results}

The results presented below are limited to the questions pertaining to the inclusion of all students, ELLs, and students with LDs. The pre questionnaire findings are offered first, followed by the post questionnaire results. For each questionnaire, the results pertaining to the inclusion of ELLs is followed by the results for students with LDs.

\section{Pre-Questionnaire Results}

The pre-questionnaire results are presented in two tables: Table 2 provides the findings from the Likert-scale items focusing on the inclusion of ELLs; Table 3 offers the results on the items pertaining to inclusion of students with LDs.

Table 2

Number of Respondents Indicating Their Agreement to Pre-Questionnaire Items About ELLs in FSL Classes, by Practicum Program ${ }^{4}$

\begin{tabular}{lccccc}
\hline ELLs in FSL classes & $\begin{array}{c}\text { Core } \\
\text { French } \\
(\boldsymbol{n}=\mathbf{2 4})\end{array}$ & $\begin{array}{c}\text { French } \\
\text { Immersion } \\
(\boldsymbol{n}=\mathbf{1 6})\end{array}$ & $\boldsymbol{\chi}^{\mathbf{2}(\mathbf{1})}$ & $\boldsymbol{p}$ & $\begin{array}{c}\text { Effect Size } \\
\text { (Cohen's } \boldsymbol{h})\end{array}$ \\
\hline $\begin{array}{l}\text { 1. I believe ELLs should be included } \\
\text { in core FSL classes. }\end{array}$ & 23 & 16 & 0.00 & 1.00 & $0.41^{*}$ \\
$\begin{array}{l}\text { 2. I believe ELLs should have the } \\
\text { opportunity to enroll in French } \\
\text { immersion, where available. }\end{array}$ & 23 & 16 & 0.00 & 1.00 & $0.41^{*}$ \\
$\begin{array}{l}\text { 3. All students should be a part of } \\
\text { the core French learning } \\
\text { classroom. }\end{array}$ & 23 & 15 & 0.00 & 0.99 & 0.29 * \\
$\begin{array}{l}\text { 4. All students should have the } \\
\text { opportunity to be part of French } \\
\text { immersion, where available. }\end{array}$ & 23 & 14 & 0.14 & 0.71 & $0.31^{*}$ \\
\hline
\end{tabular}

${ }^{*}$ small effect size

As seen in Table 2 pertaining to the inclusion of ELLs, on all of the items the vast majority of respondents with experience in both programs were positive toward their inclusion. Although not at the level of statistical significance, when examining the descriptive data, teacher candidates with French immersion experience were more agreeable than those with core French experience on two of the four items. In general, teacher candidates with immersion experience responded more positively to the items that pertained to the inclusion of ELLs precisely, as compared to the items that addressed inclusion of all students. The chi-square was not significant, and the strength of the differences was small.

Similar to the results found in Table 2, the majority of respondents were positive about the inclusion of students with LDs, as shown in Table 3. The descriptive data revealed that teacher candidates with French immersion experience responded more

\footnotetext{
${ }^{4}$ In observance of our ethical protocol, participants were able to skip questions they preferred not to answer, resulting in a different number of participants for some questions.
} 
positively to the inclusion of students with LDs in core French, whereas teacher candidates with core French experience were more positive about the inclusion of all students in immersion. The groups' responses, as reflected in the descriptive data, did not differ on the item pertaining to the inclusion of students with LDs in immersion. No to All chi-square analyses were not significant, but small differences were found with the effect size analysis.

Table 3

Number of Respondents Indicating Their Agreement to Pre-Questionnaire Items About Students with LDs in FSL Classes, by Practicum Program

\begin{tabular}{lccccc}
\hline Students with LDs in FSL classes & $\begin{array}{c}\text { Core } \\
\text { French } \\
(\boldsymbol{n}=\mathbf{2 4})\end{array}$ & $\begin{array}{c}\text { French } \\
\text { Immersion } \\
(\boldsymbol{n}=\mathbf{1 6})\end{array}$ & $\boldsymbol{\chi}^{\mathbf{2}(\mathbf{1})}$ & $\boldsymbol{p}$ & $\begin{array}{c}\text { Effect Size } \\
\text { (Cohen's } \boldsymbol{h})\end{array}$ \\
\hline $\begin{array}{c}\text { 1. I believe that students with LDs } \\
\text { should be included in core French. }\end{array}$ & 23 & 16 & 0.0 & 1.0 & $0.41^{*}$ \\
$\begin{array}{c}\text { 2. I believe that students with LDs } \\
\text { should be included in French } \\
\text { immersion, where available. }\end{array}$ & 21 & 14 & 0.0 & 1.0 & 0.00 \\
$\begin{array}{l}\text { 3. All students should have the } \\
\text { opportunity to be part of French } \\
\text { immersion, where available. }\end{array}$ & 23 & 14 & 0.14 & 0.71 & $0.31^{*}$ \\
\hline
\end{tabular}

${ }^{*}$ Note: Question regarding core French inclusion was removed as respondents chose more than one option, ${ }^{*}$ small effect size

\section{Post-Questionnaire Results}

Upon completion of the teacher preparation program, respondents completed a post questionnaire. As above, the results in Table 4 were tabulated according to program of experience. Overall, comparable to the pre-questionnaire descriptive data, as it pertains to the inclusion of ELLs, the vast majority of respondents with experience from both programs were positive toward their inclusion. Teacher candidates with French immersion experience were more agreeable than those with core French experience on three of the four items. As with the pre questionnaire, they were less agreeable that all students should be included in French immersion. While small differences were found between respondents with core and immersion experiences on the pre questionnaire, all four items revealed medium effects on the post questionnaire. Such effects suggest that program experience may influence teacher candidates' views on inclusion.

In general, the vast majority of all respondents were positive about the inclusion of students with LDs in the post questionnaire, as presented in Table 5. The descriptive data showed that respondents with immersion experience responded more favourably to two of the three items regarding the inclusion of students with LDs, compared to their colleagues who had experiences in the core French context. The chi-square, however, was not significant, and where differences were found, they were small. 
Table 4

Number of Respondents Indicating Their Agreement to Post-Questionnaire Items About ELLs in FSL Classes, by Practicum Program

\begin{tabular}{lcccccc}
\hline ELLs in FSL classes & $\begin{array}{c}\text { Core } \\
\text { French } \\
(\boldsymbol{n}=\mathbf{2 4})\end{array}$ & $\begin{array}{c}\text { French } \\
\text { Immersion } \\
(\boldsymbol{n}=\mathbf{1 6})\end{array}$ & $\chi^{\mathbf{2}(\mathbf{1})}$ & $\boldsymbol{p}$ & $\begin{array}{c}\text { Effect Size } \\
(\text { Cohen's } \boldsymbol{h})\end{array}$ \\
\hline $\begin{array}{l}\text { 1. I believe ELLs should be } \\
\text { included in core FSL classes. }\end{array}$ & 21 & 16 & 0.74 & 0.39 & $0.72^{* *}$ \\
$\begin{array}{l}\text { 2. I believe ELLs should have the } \\
\text { opportunity to enroll in French } \\
\text { immersion, where available. }\end{array}$ & 22 & 16 & 0.20 & 0.66 & $0.59^{* *}$ \\
$\begin{array}{l}\text { 3. All students should be a part of } \\
\text { the core French learning } \\
\quad \text { classroom. }\end{array}$ & 22 & 16 & 0.20 & 0.66 & $0.59^{* *}$ \\
$\begin{array}{l}\text { 4. All students should have the } \\
\text { opportunity to be part of French } \\
\text { immersion, where available. }\end{array}$ & 24 & 15 & 0.04 & 0.84 & $0.50^{* *}$ \\
\hline${ }^{*}$ Small effect size, ${ }^{* *}$ medium effect size & & & & & \\
\hline
\end{tabular}

Table 5

Number of Respondents Indicating Their Agreement to Post-Questionnaire Items About Students with LDs in FSL Classes, by Practicum Program

\begin{tabular}{lccccc}
\hline Students with LDs in FSL classes & $\begin{array}{c}\text { Core } \\
\text { French } \\
(\boldsymbol{n}=\mathbf{2 3})\end{array}$ & $\begin{array}{c}\text { French } \\
\text { Immersion } \\
(\boldsymbol{n}=\mathbf{1 4})\end{array}$ & $\boldsymbol{\chi}^{\mathbf{2}(\mathbf{1})}$ & $\boldsymbol{p}$ & $\begin{array}{c}\text { Effect Size } \\
\text { (Cohen's } \boldsymbol{h})\end{array}$ \\
\hline $\begin{array}{c}\text { 1. I believe that students with LDs } \\
\text { should be included in core French. }\end{array}$ & 18 & 13 & 0.50 & 0.48 & $0.43^{*}$ \\
$\begin{array}{c}\text { 2. I believe that students with LDs } \\
\text { should be included in French } \\
\text { immersion, where available. }\end{array}$ & 20 & 11 & 0.04 & 0.83 & $0.22^{*}$ \\
$\begin{array}{l}\text { 3. All students should have the } \\
\text { opportunity to be part of French } \\
\text { immersion, where available. }\end{array}$ & 21 & 13 & 0.00 & 1.00 & $0.06^{*}$ \\
\hline
\end{tabular}

${ }^{*}$ Note: Item regarding inclusion of all students in core French was removed as respondents chose more than one option; "small effect size; **medium effect size

In summary, the vast majority of teacher candidates were positive about including ELLs and students with LDs in core and immersion programs. Where differences in effect size were noted, teacher candidates with immersion teaching experience were more positive toward the inclusion of ELLs in both programs and toward the inclusion of all students in core French, as noted in the post questionnaire. They were also more positive toward inclusion of students with LDs in core French in the post questionnaire. That is to 
say, teacher candidates with immersion experience held more inclusive views about ELLs in all programs, all students in core French programs, and students with LDs in core French. It is worthy to note that immersion experience did not prove influential in teacher candidates' views of inclusion of all students in immersion, nor students with LDs in immersion. In other words, teacher candidates with experience in French immersion were more inclined to favour ELLs in immersion and to favour core French as the context for all students and those with LDs. Therefore, where differences were noted, the teacher candidates with French immersion experiences were more inclined to favour inclusion in core French programs. Medium effect-size differences were noted only on postquestionnaire items, suggesting that program of experience may prove influential on teacher candidates' perceptions.

\section{Interview Findings}

Participants. A subset of eight teacher candidates, who had had opportunities to teach FSL, also participated in interviews at the conclusion of their B.Ed. program. Three of them had teaching experience in French immersion, two in core French, and three teacher candidates had experience instructing in both programs. As part of the interview protocol, teacher candidates identified the program they judged to be most beneficial for ELLs and for students with LDs, and then, the opposite: They identified which program would be least beneficial. The data from those questions were then analyzed according to the program experience of the teacher candidate with a view to examining whether and how program experiences impact recommendations for students.

Interview findings for ELLs. Teacher candidates were asked to identify the best FSL program for ELLs. In general, the responses $(n=6)$ were divided, with three teacher candidates recommending immersion and the other three judging core French to be the best program for ELLs. Of the three respondents who had immersion experience, two recommended French immersion and one recommended core French; of the two who had experience in both programs, one recommended immersion and the other core. Of those who had core French experience, one judged core French to be the best context for ELLs to learn French, whereas the other identified immersion as being more beneficial. As reasons to support core French for ELLs, the candidates offered a need to focus on English and the opportunity to be on the same level as their peers.

If they were starting off school young, like in elementary school, and then they could follow the core French, it offers from Grade 4 to, like let's say they moved from, I don't know, China, at age six, and had to learn English just to get through, I'd say once they got to Grade 4, keep them in the core French. (Participant with immersion experience, J)

Core, because in the core program everyone's a beginner I think, and that way they'll be on the same level as those who speak English as well. (Participant with core experience, $\mathrm{M}$ )

Alternatively, those who preferred immersion as the program of choice for ELLs grounded their choice in the program itself and the ability to transfer skills.

French immersion, because when you're surrounded by French, it is so much easier to get the language quickly. (Participant with immersion experience, A) 
To be honest, probably immersion ... It's a lot, you can use your previous experience and your ideas a lot better in sort of a freer environment. If they were going to be going through the process of learning English, they can use those same tools to learn French, and the immersion context would allow them a bit more freedom to explore their ideas at an intellectual level. (Participant with core experience, R)

The opposite question - which program did they judge to be the worst FSL context for ELLs - had the opposite responses, as anticipated, except in one instance in which core French was identified as both the best and the worst by a candidate who had taught in both programs. However, it is important to note that when that teacher candidate identified core French as the best option, she did so due to her negative judgment of the program.

I would say core, yeah, I don't think that the students actually learn French, and I think that the students can get by without ever being able to pick it up or learn, which I hate to say this because it sounds painful, but it almost makes it a waste of time, like if you're going to designate three years of a class that there's no visible improvement at the end, it's kind of, it doesn't make sense. (Participant with experience in both programs, $\operatorname{Tr}$ )

In summary, the answers for the best program for ELLs to learn French provided a variety of answers that did not correspond to the program experiences of the teacher candidates, but that were based on negative judgments of the core French program and on positive judgments of immersion. Core French, whether recommended or not, was described as less demanding and therefore as allowing ELLs to meet not only the FSL demands, but also the demands of learning English at the same time.

Upon identifying the worst program, both teachers with experience in both programs identified core French, as did two of those with immersion experience and one with core experience. So although the judgment of the worst FSL program for ELLs did not necessarily correspond to the teacher candidates' experiences, the vast majority of the interviewees determined that core French was the worst choice. The interviews elaborated that core French was a negative choice due to the program's perceived lack of intensity, the teacher's use of English, and a lack of motivation among students.

Core French, because it's just 30 minutes every day and that's not enough.

(Participant with immersion experience, A)

Worst, I think currently probably a core French option ... just because often times our teachers right now may not have a vast view of the French language, so they're teaching French by using English, so you're using a language that they don't understand to teach them another language that they don't understand, and it's kind of pointless, so that would probably be the worst situation. (Participant with immersion experience, $\mathrm{W}$ )

Core French, because it's like half an hour or 45 minutes every so often, and the other Canadian-born kids then to have quite a negative attitude towards it, which rubs off on the ELL learners as well. (Participant with experience in both core and immersion, Ta)

In summary, the interview findings showed the teacher candidates' program recommendations for ELLs to be grounded in their judgments of the quality of program rather than in their program experiences. The teacher candidates judged the core French 
program as lower quality, which at times led them to recommend the program for ELLs (to allow them to focus on English, for example), and at other times to discourage core French as the choice for ELLs.

Interview findings for students with LDs. The teacher candidates were asked the same questions - that is, regarding the best and worst context for learning FSL-for students with LDs. As with the ELL data above, the recommendations of the best FSL context for students with LDs did not correspond to the teacher candidates' program experiences. Of the two candidates who had immersion experiences, one recommended core and the other immersion. Of the two who had core experience, one cited core whereas the other was noncommittal. The two candidates who had experience in both programs both recommended core. Although the recommendations did not necessarily correspond to the program in which the teacher candidates had experience, the majority of interviewees recommended core French as the program most suitable for students with LDs. Teacher candidates identified the lesser demands of the core French program as support for their choice:

I think core is the best for students with learning disabilities ... Just because, I know in my personal instruction I find that I do a lot more hands-on ... tasks with the students. Have them moving around a little bit more than I do in, let's say, an immersion class where we have to study novels and write essays. So I find that core has a little bit more leeway, let's say, to do fun activities, to have the students moving around, addressing a lot, addressing a lot more different learning styles. (Participant with core experience, $\mathrm{M}$ )

I find that they have a difficult enough time with core; I'm not sure if it's because of their behavior. I'm not sure they would be able to focus enough, or retain enough information in immersion. (Participant with experience in both programs, C)

Only five candidates responded to the question of the worst FSL program for students with LDs. As anticipated, the responses contrasted with those for the best program, and therefore again did not correspond to the program experiences of the teacher candidates. Three candidates stated that immersion was the worst program for students with LDs, and two selected core. The teacher candidates who did not recommend immersion cited the demands of the program in support of their choice.

I mean, you're learning all of your subjects in French, and you're going at it like crazy. (Participant with immersion experience, J)

For those who chose core French as the worst option for students with LDs, lack of program quality was cited as reasoning for their choice, in responses in which reasoning was offered.

Well, if the goal is learning French I think core French is the worst. (Participant with immersion experience, A)

In summary, in general the teacher candidates recommended core French as the best context for FSL students with LDs. The teacher candidates supported their preference for core French for students with LDs, not grounded in their experience or in the program's ability to have greater success with students with LDs, but due to its lesser demands. 


\section{Conclusion}

This study sought to explore links between teacher candidates' experiences with particular FSL programs during their B.Ed. year and their perceptions of how these programs did or did not align with the needs of LD and ELL student populations within the FSL class.

Considering both the quantitative and qualitative data sets, the questionnaire findings showed that teacher candidates with experience in French immersion were more inclined to favour ELLs in core and immersion programs, all students in core programs, and students with LDs in core French. Results from the interviews suggests that such findings may not have a foundation in the B.Ed. candidates' teaching program experience, but rather in their judgment of the programs and of the needs of the student groups. In general, the teacher candidates described the core French program as less demanding and therefore a possibility for ELLs and students with LDs, largely guided by the belief that these students could place their attention elsewhere (e.g., on other subjects under study). In contrast, teacher candidates judged the French immersion program to be of higher quality but at times too demanding for LD and ELL students, perceptions which seem to perpetuate a stance that French immersion is not a program that is "suitable" for all students.

This revelation - that the basis for favouring core French lay in teacher candidates' judgments about students' needs for and abilities to meet the demands of the French immersion program - can provide direction to FSL teacher educators for enhancing teacher candidates' recognition that ELLs and students with LDs can meet with success in immersion (e.g., Genesee, 2007; Mady, 2015). Such an understanding could allow for improved progress toward greater inclusion, as encouraged by a variety of Canadian provincial ministries of education (e.g., Alberta Education, 2013; Ontario Ministry of Education, 2015).

Moving forward with further research, there could be value in exploring whether or how teacher candidate perceptions of these FSL programs and of student needs could possibly evolve as they begin work in their own classrooms. Likewise, it would be informative to determine whether teacher perceptions of these FSL programs create bias in decision making when recommending program options to their students.

\section{References}

Alberta Education. (2013). Resources to support students with diverse learning needs for francophone and French immersion schools. Edmonton, AB: Author.

Arnett, K. (2003). Teacher adaptations in core French : A case study of one Grade 9 class. The Canadian Modern Language Review, 60(2), 173-198.

Arnett, K. (2010). Scaffolding in a Grade 8 core French classroom: An exploratory case study. The Canadian Modern Language Review, 66(4), 557-582.

Arnett, K. (2013). The genesis and perpetuation of exemptions and transfers from French

Second Language programs for students with diverse learning needs: A

preliminary examination and their link to inclusion. In K. Arnett \& C. Mady (Eds.), Minority populations in Canadian second language education (pp. 103-117). Bristol, UK: Multilingual Matters. 
Boone, H., \& Boone, D. (2012). Analyzing Likert data. Journal of Extension, 50, 2. Retrieved from: http://www.joe.org/joe/2012april/tt2.php

Canadian Parents for French. (2012). The proceedings of the Canadian Parents for French roundtable on academically challenged students in French-second-language programs. Ottawa, ON: author.

Carr, W. (2007). Canada's bilingualism dream: A case study of Intensive French (Unpublished doctoral dissertation). Simon Fraser University, Burnaby, BC.

Cohen, J. (1988). Statistical power analysis for the behavioral sciences (2nd ed.). Lawrence Erlbaum.

Genesee, F. (1976). The role of intelligence in second language learning. Language Learning, 26, 267-280.

Genesee, F. (1990). Beyond bilingualism: Sociocultural studies in immersion. In B. Flemming \& M. Whitla (Eds.), So you want your child to learn French! (pp. 96-107). Ottawa, ON: Canadian Parents for French.

Genesee, F. (2006). The suitability of French Immersion for students who are at-risk: A review of research evidence. Report prepared for Canadian Parents for French, Ottawa, ON.

Genesee, F. (2007). French immersion and at-risk students: A review of research evidence. Canadian Modern Language Review, 63(5), 655-688.

Knouzi, I., \& Mady, C. (2014). Voices of resilience from the bottom rungs: The stories of three elementary core French teachers in Ontario. Alberta Journal of Educational Research, 60(1), $62-80$.

Lapkin, S., MacFarlane, A., \& Vandergrift, L. (2006). Teaching French in Canada: FSL teachers' perspectives. Ottawa, ON: Canadian Teachers' Federation.

Lazaruk, W. A. (2007). Linguistic, academic, and cognitive benefits of French immersion. Canadian Modern Language Review, 63(5), 605-628.

Le Bouthillier, J. (2013). The writing processes of a Grade 7 French immersion student with Asperger syndrome. In K. Arnett \& C. Mady (Eds.), Minority populations in second language education: Broadening the lens from Canada. Bristol, UK: Multilingual Matters.

Mady, C. (2007a). Allophone students in second-official language programs. Canadian Modern Language Review, 63(5), 727-760.

Mady, C. (2007b). The suitability of core French for recently arrived adolescent immigrants to Canada. Canadian Journal of Applied Linguistics, 10(2), 177-196.

Mady, C. (2015). The bilingual advantage for immigrant students in French immersion in Canada: Linking advantages to contextual variables. International Journal of Bilingual Education and Bilingualism. doi:10.1080/13670050.2015.1041875

Mady, C., Arnett, K., \& Muilenburg, L. (2016). French second-language teacher candidates' positions towards allophone students and implications for inclusion. The International Journal of Inclusive Education. doi:10.1080/13603116.2016.1184330

Mady, C., \& Black, G. (2012). Access to French as a second official language programs in Englishdominant Canada. Alberta Journal of Educational Research, 57(4), 498-501.

Maher, J., Markey J., \& Ebert-May, D. (2013). The other half of the story: Effect size analysis in quantitative research. Life Sciences Education, 12(3), 345-351.

Mannavarayan, J. M. (2002). The French immersion debate: French for all or all for French? Calgary, AB: Detselig Enterprises. 
Mollica, A., Phillips, G., \& Smith, M. (2005). Teaching and learning French as a second language: Core French in the elementary schools of Ontario. Burlington, ON: Ontario Modern Language Teachers Association.

Ontario Ministry of Education. (2015). Including students with special education needs in French as a second language programs. Toronto, ON: Author.

Porter, G., \& AuCoin, A. (2012). Strengthening inclusion, strengthening schools. Fredericton, NB: Department of Education and Early Childhood Development.

Rousseau, N. (1999). A French immersion learning disabilities program: Perspectives from students, their parents, and their teachers. Mosaic, 6, 16-26.

Statistics Canada. (2011). 2011 Census of Canada: Topic-based tabulations. Retrieved from http://www12.statcan.gc.ca/census-recensement/2011/dp-pd/tbt-tt/Rpeng.cfm? $\mathrm{LANG}=\mathrm{E} \& \mathrm{APATH}=3 \& \mathrm{DETAIL}=0 \& \mathrm{DIM}=0 \& \mathrm{FL}=\mathrm{A} \& \mathrm{FREE}=0 \& \mathrm{GC}=0 \& \mathrm{GID}=0 \&$ $\mathrm{GK}=0 \& \mathrm{GRP}=1 \& \mathrm{PID}=103001 \& \mathrm{PRID}=0 \& \mathrm{PTYPE}=101955 \& \mathrm{~S}=0 \& \mathrm{SHOW} A L L=0 \& \mathrm{SUB}=0 \&$ Temporal $=2011 \&$ THEME $=90 \& \mathrm{VID}=0 \& \mathrm{VNAMEE}=\& \mathrm{VNAMEF}=$

Swain, M., \& Lapkin, S. (2005). The evolving sociopolitical context of immersion education in Canada: Some implications for program development. International Journal of Applied Linguistics, 15(2), 169-186.

Swain, M., Lapkin, S., Rowen, \& Hart, D. (1990). The role of mother tongue literacy in third language learning. Journal of the Australian Advisory Council on Languages and Multicultural Education, 4, 111-121.

Taaffe, R., Maguire, M., \& Pringle, I. (1996). The impact of social contexts and educational policy/practice on biliteracy development: Ethnolinguistic minority children in English primary schools in Ottawa and Montreal. Journal of the CAAL, 18(2), 85-101.

Taylor, S. (1992). Victor: A case study of a Cantonese child in early French immersion. Canadian Modern Language Review, 48(4), 736-759.

Thomas, R., \& Mady, C. (2014). Teaching for transfer: Insights from theory and practices in primarylevel French-second-language classrooms. McGill Journal of Education, 49(2), 399-416.

\section{Authors' Note}

Correspondence concerning this article should be addressed to Katy Arnett, Department of Educational Studies, St. Mary's College of Maryland, 47645 College Drive, St. Mary's City, MD 20686. Email: kearnett@smcm.edu 


\section{Appendix: Questionnaire}

Questionnaire, page 1

1. Names will not be used in any publications nor made available to anyone other than the two researchers. However, we ask that you provide a name here so that we might contact you for a follow-up interview.

2. Please indicate your province/state of your teacher education program.

3. Please provide contact information (email and phone number) so that we might contact you for a follow-up interview or if you are on of the five candidates to receive a complementary copy of Making Connections. Again, this information will not be published, nor will you be identified in any publications.

4. Please indicate your gender.

Male

Female

5. Please describe your post-secondary education in French, if any.

I did not study French in university.

I took one or two course (s) in French in university.

I took French as my minor.

I took French as my major.

I completed my university studies at a francophone institution.

6. Indicate if you have had experience teaching French.

No, I have not yet taught French.

Yes, for 1-6 months.

Yes, for 6-12 months.

$\bigcirc$ Yes, for between 1-2 years.

$\bigcirc$ Yes, for between 2 to 5 years.

Yes, for more than 5 years 
Questionnaire, page 2

7. If you have had experience teaching French, in which program (s) did you teach? (Please check all that apply)

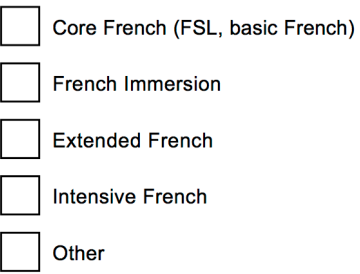

If other, please elaborate

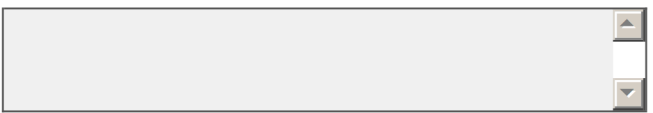

8. What kinds of courses are you completing at your Faculty of Education that are related to FSL teaching? (please check all that apply)

$\square$ a course or courses in FSL methodology (core French and immersion)

$\square$ a course or courses in core French methodology

$\square$ a course or courses in immersion methodology

$\square$ a course or courses in how to teach other subjects in French

did not attend a Faculty of Education

Other (please specify)

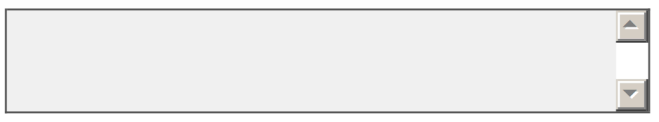

9. What level (s) will you be qualified to teach? (Check all that apply)

Primary (K-Grade 3)

Junior (Grades 4-6)

Intermediate (Grades 7-10)

$\bigcirc$ Senior (Grades 11-12)

10. Do you have an additional language (in addition to French and English)?

Yes

$\bigcirc$ No

If yes, what language (s) do you know? And how did you learn it/them?

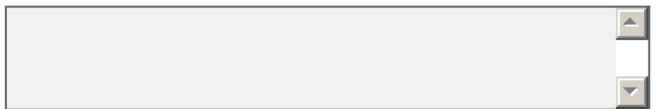


Questionnaire, page 3

11. This section of the questionnaire pertains to: English language learners in French second language classes.

Please indicate your agreement/disagreement with the following statements.

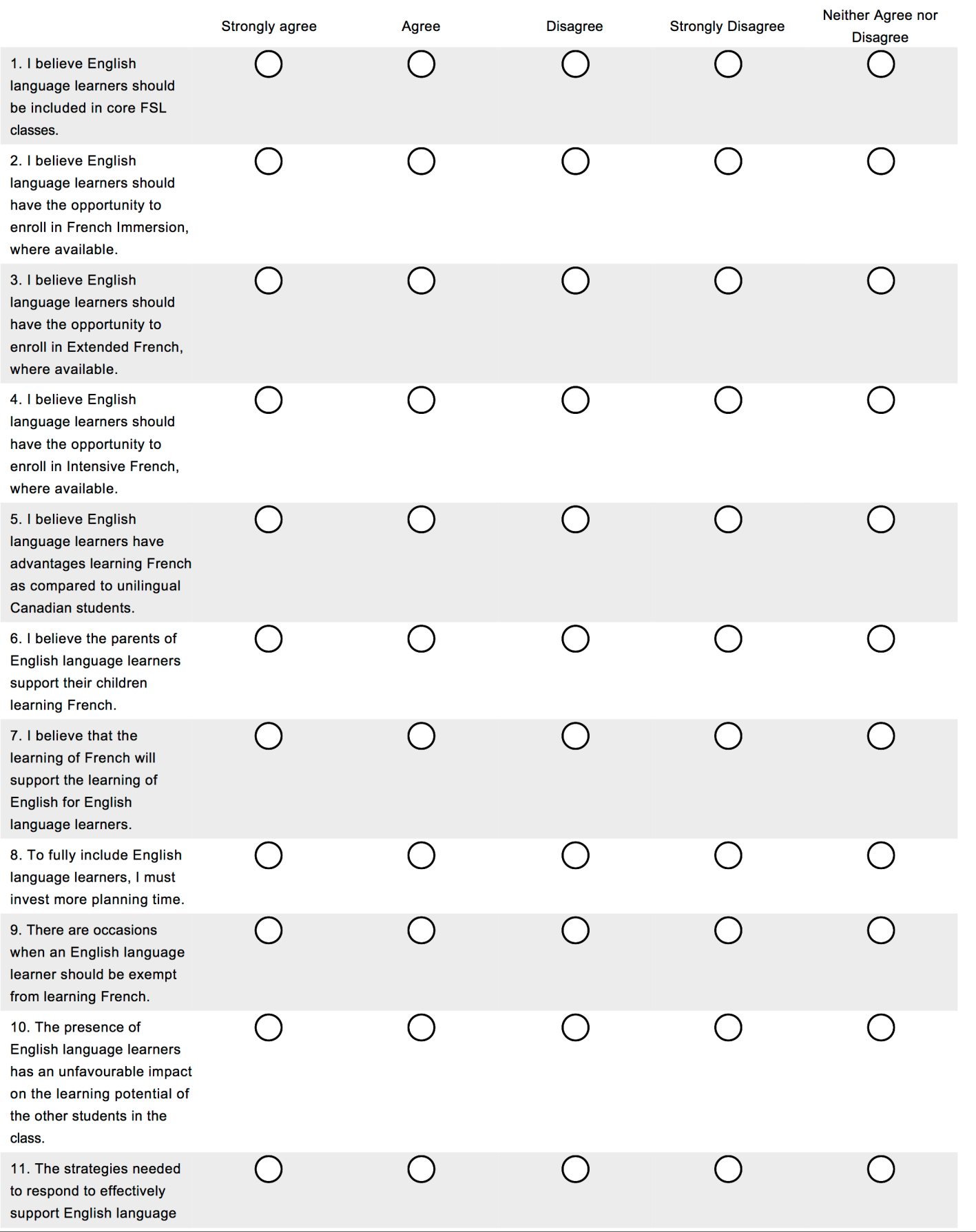


Questionnaire, page 4

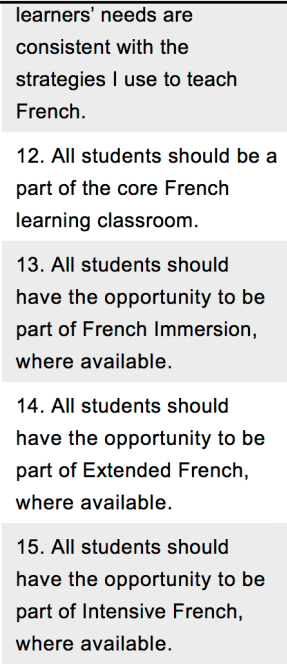

12. What strategies could you use to meet English language learners' needs in FSL?

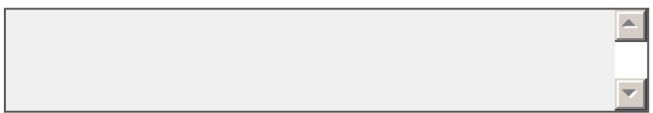

13.

We welcome any additional information you would like us to consider concerning the inclusion of English language learners in FSL.

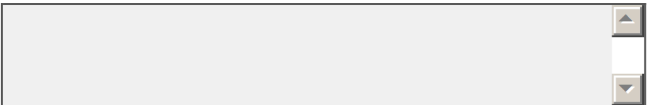

14. Does any person in your immediate family have learning difficulties?

Yes

$\bigcirc$ No

If yes, please specify

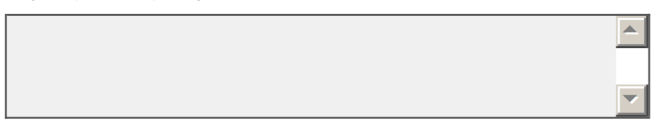

15. Do you have identified learning difficulties?

Yes

No

If yes, please specify

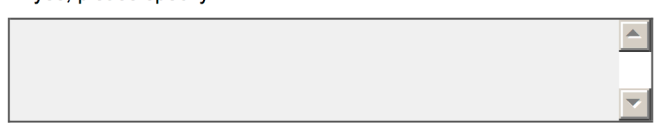


Questionnaire, page 5

16. This section of the questionnaire pertains to: students with learning difficulties in French second language classes. Please indicate your agreement/disagreement with the following statements.

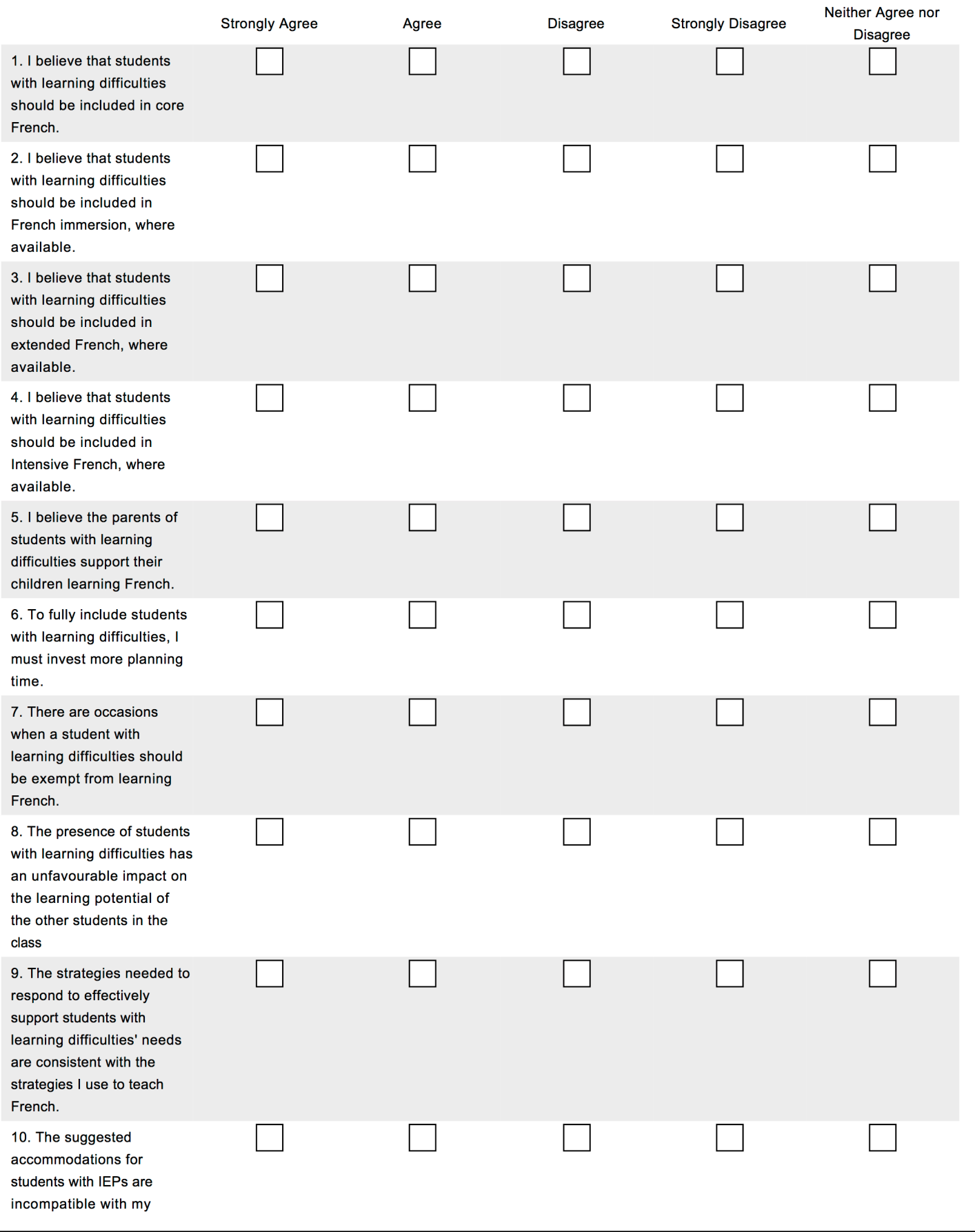


Questionnaire, page 6

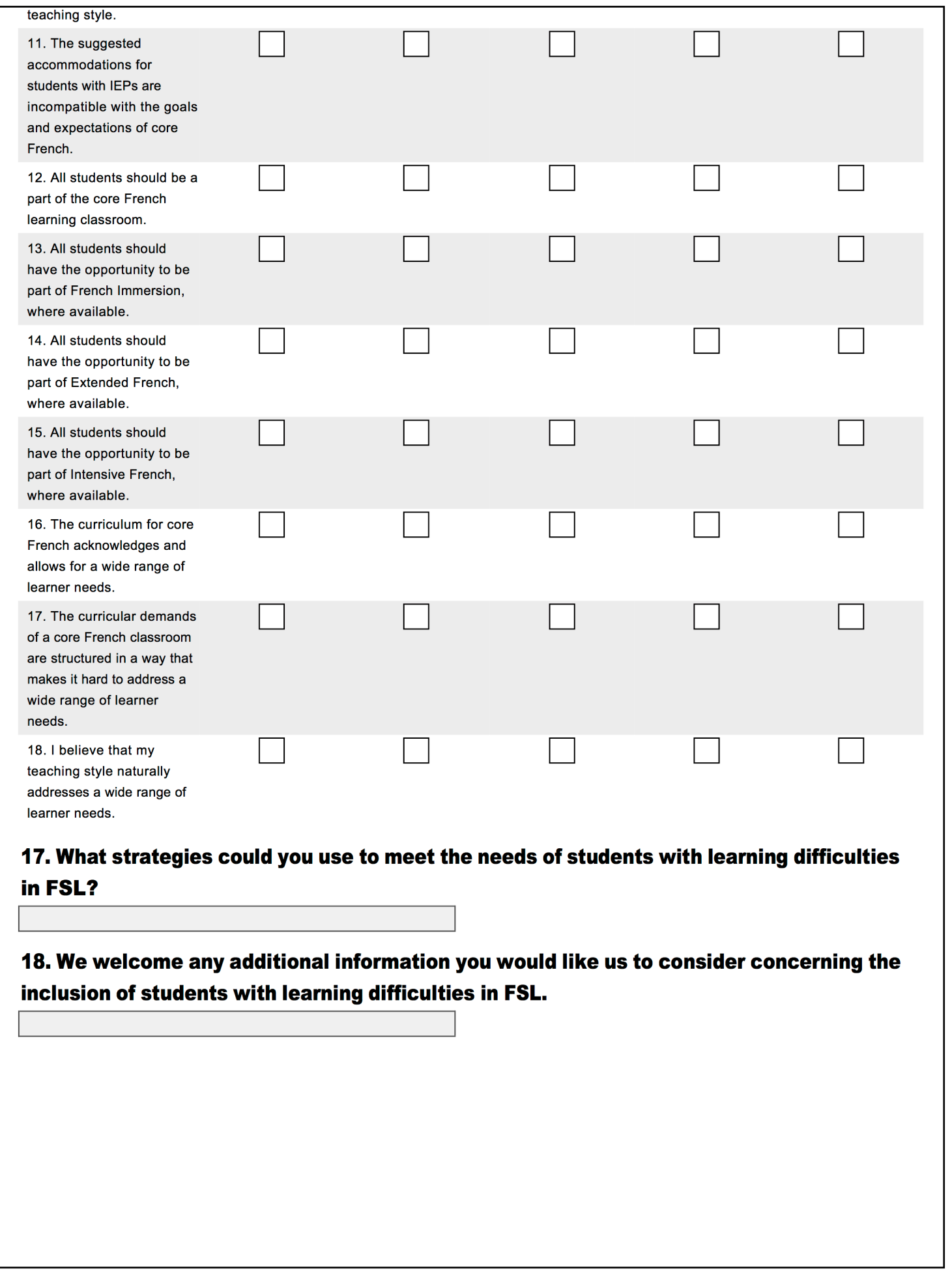

